\title{
De tien herziene standaards van het IASC
}

\author{
Drs. C.A. Arnold
}

\section{Inleiding'}

De laatste decennia is er sprake geweest van een toenemende mate van internationalisering van zowel het bedrijfsleven als de kapitaalmarkten. Door de internationalisatie van kapitaalmarkten is de behoefte van gebruikers van financiële informatie, die zich op deze markten richten, aan geharmoniseerde financiële informatie vergroot.

In het internationale harmonisatieproces is met name het International Accounting Standards Committee (IASC) bijzonder actief. Het IASC is in 1973 opgericht en houdt zich bezig met het uitvaardigen van standaards op het gebied van de financiële verslaggeving van organisaties. Tot en met augustus 1993 heeft het IASC 31 standaards goedgekeurd en uitgegeven, waarvan er 29 nog steeds gelden.

De laatste jaren tracht het IASC harmonisatie van jaarverslaggeving tot stand te brengen door het aantal opties in de diverse International Accounting Standards (IAS) te verminderen, waarbij zij wordt gesteund door de internationale organisatie van toezichthoudende organen op de beurs, de IOSCO (International Organisation of Securities exchange COmmissioners). Dit staat bekend onder het 'Comparability/Improvements Project'. In de eerste fase ervan is een Statement of Intent (SI) gepubli-

Drs. C.A. Arnold studeerde (bedrijfs)economie en studeert accountancy aan de VU Amsterdam. Hij is als universitair docent verbonden aan de vakgroep Kosten- en winstvraagstukken (FEWEC) van de VU. Sinds 1994 verricht hij promotieonderzoek op het gebied van de behoefte aan geharmoniseerde financiële informatie. ceerd waarin er naar is gestreefd het aantal opties voor waardering en resultaatbepaling dat tot dat moment in de fïnanciële verslaggeving bestond, belangrijk terug te brengen. In het kader van dit project zijn voorts door de Board van het IASC nieuwe Exposure Drafts (ED) van herziene IASCstandaards uitgegeven. Daarna zijn in het kader van dit project in november 1993 tien (herziene) standaards goedgekeurd.

In dit artikel wordt de inhoud van de tien herziene IASC-standaards behandeld, waarbij tevens de belangrijkste verschillen met de oude standaards, de SI en de ED's worden aangegeven.

Om een indruk te krijgen van de mate waarin en de punten waarop de Nederlandse regelgeving (zowel de wetgeving als de Richtlijnen voor de Jaarverslaggeving) ${ }^{2}$ afwijkt van de IASC-standaards ${ }^{3}$ (en dus van de mate waarin en de punten waarop deze regelgeving zou moeten worden aangepast indien de IASC-regels erin verwerkt zouden worden), is in dit artikel tevens de Nederlandse regelgeving aangegeven. Tevens is bij veel verslaggevingspunten de Nederlandse verslaggevingspraktijk aangegeven.

Allereerst volgt in paragraaf 2 een nadere toelichting van het 'Comparability/Improvements Project', waarna in paragraaf 3 wordt ingegaan op de samenhang tussen EG-richtlijnen en IASCstandaards en de implementatie van de IASCstandaards in andere Europese landen. Paragraaf 4 behandelt de inhoud van de herziene standaards en geeft de verschillen aan tussen de herziene standaards en de oude standaards, de SI, de ED's, de Nederlandse regelgeving en op een aantal punten de Nederlandse verslaggevingspraktijk. Paragraaf 6 bevat enige afsluitende opmerkingen. 


\section{Het 'Comparability/Improvements Project'}

In januari 1989 publiceerde het IASC Exposure Draft (ontwerp standaard) E32 'Comparability of Financial Statements', waarin werd voorgesteld het aantal opties in de reeds bestaande standaards drastisch te reduceren. De vermindering van het aantal opties werd in E32 bewerkstelligd door bij veel verwerkingswijzen een voorkeursmethode ('benchmark treatment') aan te geven. Eén alternatieve methode ('allowed alternative treatment') werd alleen toegestaan indien de onderneming in de toelichting tot uitdrukking bracht welk effect toepassing van die alternatieve methode in vergelijking met de voorkeursmethode had op vermogen en resultaat (reconciliatie).

In juli 1990 volgde de publikatie van de 'Statement of Intent; Comparability of Financial Statements' (SI), waarin de voorstellen in E32 tot wijziging van de destijds van kracht zijnde 29 standaards van het IASC werden geëvalueerd. Een belangrijke wijziging in de SI ten opzichte van E32 betrof het in de meeste van de voorgestelde gevallen afschaffen van de in E32 verplicht gestelde reconciliatie naar de voorkeursmethode, indien de toegestane alternatieve verwerkingswijze werd gebruikt. De ondernemingen kregen in een groot aantal van de voorgestelde gevallen de keuze tussen twee methoden van verwerking. Zoals Klaassen terecht heeft geconcludeerd, hield dit reeds een belangrijke reductie in van het aantal opties dat tot dan toe door de IASC-standaards werd toegelaten. ${ }^{4}$

Door de goedkeuring van de SI erkende de Board van het IASC dat diverse standaards moesten worden aangepast aan de ontwikkelingen die hadden plaatsgevonden sinds de standaards voor het eerst werden gepubliceerd. Na het SI vaardigde het IASC diverse ED's uit: E37, E38 en E39 (augustus 1991), E41, E42, E43 en E44 (mei 1992) en E45 en E46 (juni 1992). De voorlopig laatste Exposure Draft in het kader van het 'comparability'-project werd uitgegeven in december 1992: E47. Op basis van de ontvangen commentaren op de Exposure Drafts zijn deze aangepast en omgezet in tien definitieve standaards, welke door de IASC-Board in haar vergadering in Oslo op 2-5 november 1993 zijn goedgekeurd. De tien herziene standaards zijn van toepassing op boekjaren die aanvangen op of na I januari 1995.

\section{Internationale harmonisatie}

Het IASC kan naleving van de door haar geformuleerde regels niet afdwingen. Een organisatie die de door haar geformuleerde regels (EGRichtlijnen) wel kan afdwingen is de Europese Gemeenschap (EG). De Vierde EG-Richtlijn (betreffende de jaarrekening van kapitaalvennootschappen) en de Zevende EG-Richtlijn (betreffende de geconsolideerde jaarrekening) legden de basis voor de harmonisatie van het jaarrekeningrecht in de EG. Beide EG-Richtlijnen zijn inmiddels in de nationale wetgeving van alle lidstaten geïncorporeerd (Nederland: 1983 respectievelijk 1988), ${ }^{5}$ en hebben in belangrijke mate tot harmonisatie in financiële verslaggevingsregels geleid. ${ }^{6}$

Uit studies van de Federation des Expert Comptables Europeens (FEE), de Europese organisatie van controleurs van financiële informatie. bleek dat een aanzienlijk aantal eisen in de Vierde EG-Richtlijn en de IASC-standaards overeenstemmen, en dat de overeenstemming wordt vergroot door het 'Comparability/Improvements Project' van het IASC. ${ }^{7}$ Een nog grotere mate van overeenstemming bestaat er tussen de eisen in de Zevende EG-Richtlijn en die in de IASC-standaards (dit zal geen verbazing wekken indien men bedenkt dat de Zevende EG-Richtlijn is gebaseerd op IAS 3 'Consolidated Financial Statements'). ${ }^{8}$ Een gevolg van deze overeenstemming is dat de meerderheid van de ondernemingen in de EG-lidstaten in staat is om hun financiële verslagen zowel conform de twee EG-Richtlijnen ${ }^{9}$ als conform de IASC-standaards ${ }^{10}$ op te stellen. Een tweede gevolg van deze overeenstemming is dat in de meerderheid van de EG-lidstaten de eisen in de nationale regelgeving in vergaande mate overeenstemmen met de eisen in de IASCstandaards."

Men kan echter constateren dat, in tegenstelling tot de IASC-regels, de twee EG-Richtlijnen ten aanzien van veel waarderingsvoorschriften in het geheel geen aanknopingspunten bieden, of dat zij een wijde range van mogelijkheden open laten en daarom ten aanzien van veel waarderingsgrondslagen maar in geringe mate tot harmonisatie leiden. ${ }^{12}$ Hierin zal in de toekomst verandering kunnen komen. De Europese Commissie participeert als waarnemer in de IASC-Board en neemt voorts deel aan de besprekingen van de Consultative Group, het IASC-orgaan dat standaards 
voorbereid. Gevolg hiervan zou kunnen zijn dat de uitgegeven internationale standaards op EGtoepasbaarheid kunnen worden bezien en dat ze vervolgens aan de Europese Commissie kunnen worden aangeboden om als grondslag te dienen voor nieuwe EG-Richtlijnen of voor een herziening van bestaande EG-Richtlijnen.

Zoals in de inleiding reeds is aangegeven richt het IASC zich bij haar harmonisatiepogingen vooralsnog op andere instellingen die regels kunnen afdwingen, namelijk de beursorganisaties en dan met name de IOSCO. Binnen Nederland houdt de Stichting Toezicht op het Effectenverkeer (STE) toezicht op de handel aan de Amsterdamse Effectenbeurs. Deze stichting heeft namens Nederland zitting in het IOSCO. Het IOSCO is betrokken bij een project teneinde de door het IASC uitgevaardigde standaards bij internationale emissies te gaan erkennen als basis voor financiële verslaggeving die voldoet aan de eisen van meerdere beursen. Daardoor kan de internationaal georiënteerde onderneming in de toekomst bij een internationale emissie met één emissieprospectus volstaan. Dit kan tot aanpassing in de financiële verslaggeving van beursgenoteerde ondernemingen in Nederland leiden. ${ }^{13}$

\section{De tien herziene standaards}

\section{IAS 2 [E38] Inventories}

De standaard behandelt de waardering van voorraden van fungibele goederen in de context van historische kosten. Voorraadwaardering op basis van actuele waarde blijft buiten beschouwing.

In de oude standaard IAS 2 'Valuation and Presentation of Inventories in the Context of the Historical Cost System' (oktober 1975) werd met betrekking tot de methode van voorraadwaardering de keuze vrijgelaten tussen het gebruik van First-In-First-Out (FIFO), Last-In-First-Out (LIFO), gewogen gemiddelde inkoopprijzen en het ijzeren-voorraadstelsel.

In E32 werd voorgesteld om aan FIFO de voorkeur te geven. Het LIFO-stelsel was als alternatieve methode toegestaan. wat derhalve een verplichting inhield tot reconciliatie met FIFO. Tevens werd voorgesteld het ijzeren voorraadstelsel en daaraan verwante substantialistische winstbepalingsstelsels niet langer toe te staan.
Op basis van de ontvangen commentaren op E32 werd in de SI voorgesteld om FIFO of de gewogen gemiddelde inkoopprijs te hanteren. LIFO bleef een toegestaan alternatief, in tegenstelling tot het ijzeren voorraadstelsel. In E38 ging het IASC zelfs een stap verder door ook LIFO niet langer toe te staan. Op de uitsluiting van LIFO is veel commentaar gekregen, zodat in de herziene IAS 2 LIFO als alternatief weer wordt toegestaan.

In de herziene IAS 2 worden als voorkeursmethoden FIFO en gewogen gemiddelde inkoopprijzen aangeduid, en het toegestane alternatief is LIFO. Indien LIFO wordt gebruikt dient in de toelichting een reconciliatie naar FIFO te worden gemaakt.

De Nederlandse wet staat waardering tegen gewogen gemiddelde inkoopprijzen, LIFO, FIFO en het ijzeren-voorraadstelsel toe. ${ }^{14}$ Volgens de Nederlandse richtlijn dient bij gebruik van LIFO (dan wel het ijzeren-voorraadstelsel; in de richtlijn het 'vaste'-voorraadstelsel genoemd) bij voorraadwaardering de actuele waarde in de balans of in de toelichting te worden opgenomen [RJ 2.11.504]. Er is derhalve sprake van een gering verschil (reconciliatie naar FIFO (IAS 2) of vermelding van de actuele waarde (RJ 2.11.504)) tussen de herziene IAS 2 en de Nederlandse regelgeving. In de Nederlandse verslaggevingspraktijk komen LIFO en het ijzeren voorraadstelsel relatief weinig voor. ${ }^{15}$

\section{IAS 8 [E46] Net Profit or Loss for the Period, Fundamental Errors and Changes in Accounting Policies}

De standaard behandelt de administratieve verwerking van het nettoresultaat, de correctie van fundamentele fouten en stelselwijzigingen in de jaarrekening.

De oude standaard IAS 8 'Unusual and Prior Period Items and Changes in Accounting Policies' (februari 1978) bevatte de behandeling van 'ongebruikelijke posten', oftewel buitengewone posten, die in de nettowinst begrepen dienden te worden en elk afzonderlijk dienden te worden toegelicht. 'Ongebruikelijk' zijn die posten die voortvloeien uit gebeurtenissen of transacties die zich onderscheiden van normale bedrijfsactiviteiten en dientengevolge naar verwachting niet vaak of regelmatig voorkomen. In E32, de SI en E46 en ook in de herziene IAS 8 is het begrip 'buitengewoon 'ingeperkt. Volgens de herziene IAS 8 zijn baten en lasten slechts buitengewoon indien ze 
voortvloeien uit zeldzame gebeurtenissen of transacties (zoals bijvoorbeeld een aardbeving of onteigening van activa). Baten en lasten zijn volgens de Nederlandse wetgeving buitengewoon indien ze niet voortvloeien uit gewone bedrijfsuitoefening [Art. 377.7] . De definitie volgens IAS 8 is derhalve aanzienlijk restrictiever dan volgens de Nederlandse wetgeving.

Posten van vorige boekjaren (ontstaan als gevolg van fundamentele fouten) dienden volgens de oude IAS 8, net als het cumulatieve effect van stelselwijzigingen, rechtstreeks ten laste van het eigen vermogen te komen of in de winst- en verliesrekening als onderdeel van de nettowinst in het boekjaar te worden opgenomen. Hierbij dienden de ter vergelijking opgenomen gegevens over voorgaande boekjaren te worden aangepast.

In E32 gaf het IASC aan dat ten aanzien van de verwerking de correctie van fundamentele fouten en het cumulatieve effect van stelselwijzigingen de voorkeur uitging naar rechtstreekse verwerking in het eigen vermogen en aanpassing van de cijfers van voorgaande boekjaren. Toegestaan alternatief was de verwerking in de winsten verliesrekening in het boekjaar, waarbij een reconciliatie naar de voorkeursmethode moest worden gemaakt. In dat geval werden uiteraard de vergelijkende cijfers niet aangepast.

In de SI werd voor de correctie van fundamentele fouten en voor de verwerking van het cumulatieve effect van stelselwijzigingen het onderscheid tussen voorkeurs- en alternatieve methode zoals voorgesteld in E32 gehandhaafd. Wel werd de voorkeursmethode iets versoepeld: rechtstreekse verwerking in het eigen vermogen, met aanpassing van vergelijkende cijfers van voorgaande jaren, tenzij dit laatste niet praktisch is en dit feit wordt vermeld in de toelichting. In E46 en in de herziene IAS 8 werden ten opzichte van de SI op deze punten geen belangrijke wijzigingen aangebracht. In de herziene IAS 8 is een appendix ter verduidelijking toegevoegd en is de verplichting tot reconciliatie losgelaten.

Ten aanzien van de verwerking van de correctie van fundamentele fouten zijn in de Nederlandse regelgeving geen regelingen opgenomen. De Richtlijnen voor de Jaarverslaggeving (RJ) spreken ten aanzien van de verwerking van het cumulatieve effect van stelselwijzigingen de voorkeur uit voor aanpassing van het eigen vermogen [RJ 1.06.110]. Verwerking in het netto resultaat van het boekjaar is toegestaan. Bij beide methoden schrijft de wet voor dat de vergelijkende cijfers moeten worden aangepast [Art. 363.5]. In de Nederlandse verslaggevingspraktijk komen de twee hoofdmethoden ter verwerking van het cumulatieve effect van stelselwijzigingen (en de correctie van fundamentele fouten) naast elkaar voor. $^{16}$

De oude standaard IAS 8 behandelde tevens de verwerking van schattingswijzigingen: indien van wezenlijke invloed op verslagperiode dienen ze te worden vermeld en gekwantificeerd. Op deze eis is in E32, de SI, E46 en de herziene IAS 8 geen wijziging aangebracht. Volgens de Nederlandse richtlijnen zijn schattingswijzigingen geen stelselwijzigingen en derhalve behoeven ze ook niet als zodanig te worden behandeld [RJ $1.06 .105 \mathrm{c}$ ]. Schattingswijzigingen dienen volgens richtlijnen afzonderlijk in de winst- en verliesrekening te worden vermeld dan wel gekwantificeerd te worden toegelicht [RJ 2.02.220* en 2.71.212*]. Zie voor schattingswijzingen tevens de laatste alinea van 6. IAS 16.

In E32, de SI, E46 en ook in de herziene IAS 8 is opgenomen, dat in geval van beëindigde activiteiten welke het gevolg zijn van de verkoop of afstoting van afzonderlijke, belangrijke segmenten ('discontinued operations'), deze uitgebreid dienen te worden toegelicht. In de Nederlandse richtlijnen is slechts de bepaling opgenomen, dat uit de verlies- en winstrekening of uit de toelichting het totale (netto)bedrag dient te blijken [RJ 2.71.215*].

\section{IAS 9 [E37] Research and Development Costs}

De standaard behandelt de administratieve verwerking van onderzoeks- en ontwikkelingsactiviteiten.

In de oude IAS 9 'Accounting for Research and Development Activities' (juli 1978) was er een vrije keuze mogelijk tussen activeren en het ten laste van de winst- en verliesrekening brengen van ontwikkelingskosten die aan bepaalde voorwaarden voldeden. In E32 werd er de voorkeur aan gegeven dat alle ontwikkelingskosten direct ten laste van de winst- en verliesrekening moesten worden gebracht. Activering was een toegestaan alternatief.

$\mathrm{Na}$ beschouwing van de commentaren op E32 werd in de SI en in E37 activering van ontwikkelingskosten vereist, indien aan bepaalde voorwaarden werd voldaan. Indien niet aan deze voorwaar- 
den werd voldaan, dienden de kosten direct ten laste van de winst- en verliesrekening te worden gebracht. In de herziene IAS 9 zijn de aanbevelingen volgens de SI en E37 overgenomen.

Onderzoekskosten dienden volgens de oude standaard IAS 9 als last in de periode waarin ze zijn ontstaan in de verlies- en winstrekening te worden opgenomen. In de herziene IAS 9 blijft het verbod op activering van onderzoekskosten gehandhaafd.

Volgens de Nederlandse wetgeving is het activeren van onderzoeks- en ontwikkelingskosten toegestaan, zij het onder zodanig strenge voorwaarden dat onderzoekskosten hieraan meestal niet voldoen. In geval van activering van onderzoeks- en ontwikkelingskosten dient volgens de Nederlandse wetgeving een wettelijke reserve ter grootte van het geactiveerde bedrag te worden gevormd [Art. 365.3]. In de Nederlandse verslaggevingspraktijk is het activeren van ontwikkelingskosten niet gebruikelijk. ${ }^{17}$

De oude IAS 9 verbiedt het opnieuw activeren van reeds afgeschreven kosten. In deze eis is in E32, de SI, E37 en de herziene IAS 9 geen verandering aangebracht. De Nederlandse richtlijnen verplichten conform de wettelijke bepalingen [Art. 387.5] eventueel verrichte extra afschrijvingen waarvan de oorzaak opgehouden heeft te bestaan, weer ongedaan te maken [RJ 2.01.115].

\section{IAS 11 [E42] Construction Contracts}

\section{IAS 18 [E4I] Revenue}

De standaards betreffen de administratieve verwerking van bouw- respectievelijk dienstverleningscontracten in de jaarrekening van ondernemingen.

De oude IAS 11 'Accounting for Construction Contracts' (maart 1978) en IAS 18 'Revenue Recognition' (december 1982) stonden beide twee methoden van winstneming toe: winstneming naar rato van de verrichte prestaties bij de uitvoering van het werk ('Percentage of Completion'methode) en winstneming bij oplevering c.q. voltooiing van het werk ('Completed Contract'methode).

In E32 is zowel voor bouw- als dienstverleningscontracten principieel gekozen voor de 'Percentage of Completion'-methode. Wel is het zo dat dan aan de voorwaarden moet zijn voldaan die voor toepassing van deze methode gelden, zoals een betrouwbare schatting van de opbrengsten en kosten van het project moet te maken zijn, en het project moet in fasen te verdelen zijn. Indien dit problemen oplevert dienen slechts de aan het werk toegerekende kosten te worden geactiveerd. Ook in de SI, E41 (dienstverleningscontracten), E42 (bouwcontracten) werd de 'Percentage of Completion'-methode voorgeschreven.

In de herziene IAS 11 en de herziene IAS 18 is opgenomen dat indien de uitkomst van het contract betrouwbaar kan worden vastgesteld, opbrengsten en kosten dienen te worden verwerkt op basis van de mate van gereedkomen van de contractactiviteiten op de balansdatum. Als de contractuitkomst niet betrouwbaar kan worden vastgesteld, dan dienen de opbrengsten slechts te worden verantwoord tot de mate waarin de kosten volgens het contract zijn gemaakt en voorzover de opgetreden kosten worden terugverdiend. De kosten dienen te worden verantwoord in de periode waarin zij optreden. De 'Completed Contract'-methode is derhalve niet toegestaan.

In de Nederlandse wetgeving is geen speciale regeling voor bouw- en dienstverleningscontracten opgenomen. Wel is volgens de Nederlandse wetgeving wenselijk opbrengsten en winsten te verantwoorden nadat het project is gereedgekomen ('completed contract'). Deze methode sluit het beste aan op het voorzichtigheids- annex realisatiebeginsel [Art. 384.2 respectievelijk 384.5]. Volgens Van Hoepen is deze uitleg echter te eng en het voldoen aan de voorwaarde van betrouwbare schatting van resterende kosten en opbrengsten zou reeds voldoende zijn voor toepassing onder de Nederlandse wet. ${ }^{18}$ De Nederlandse ontwerprichtlijn 2.11.4 stelt dat, indien de winst op de reeds verrichte prestaties voor het project op verantwoorde wijze kan worden bepaald, de winst dient te worden genomen naar rato van de verrichte prestaties bij de uitvoering van het werk ("percentage of completion'). Als niet aan de voorgaande voorwaarde is voldaan dient de winst geheel te worden verantwoord in het boekjaar waarin het (bouw)project wordt opgeleverd ('completed contract') [RJ 2.11.406]. In de Nederlandse verslaggevingspraktijk passen verschillende grote bouwmaatschappijen de 'Percentage of Completion method" toe. ${ }^{19}$

Ten opzichte van E42 zijn in de herziene IAS 11 nog een tweetal belangrijke veranderingen 
doorgevoerd: de definitie van een bouwcontract is gewijzigd en tevens de in de toelichting te verstrekken gegevens. In de herziene IAS 18 is verder nog opgenomen dat de opbrengst van de dienstverleningstransactic moet worden gewaardeerd tegen de reële waarde van de ontvangen of te ontvangen tegenprestatie. Tevens dienen in de toelichting gegevens te worden verstrekt over de verwerkte opbrengsten in de vorm van ruil van ongelijksoortige activa.

\section{IAS 16 [E43] Property, Plant and Equipement}

De standaard behandelt de verwerking van materiële vaste activa in de jaarrekening.

Volgens de oude standaard IAS 16 'Accounting for Property, Plant and Equipement' (maart 1982) diende de bruto boekwaarde van een materieel vast actief te zijn: hetzij de historische kostprijs, hetzij te zijn gebaseerd op herwaardering. Bij herwaardering mocht de netto boekwaarde niet uitkomen boven de indirecte opbrengstwaarde. In E32, de SI, E43 en ook in de herziene IAS 16 wordt als voorkeursmethode waardering op basis van historische kosten aangegeven. Toegestane alternatieve verwerkingswijze is het toepassen van herwaarderingen na de eerste verwerking. In de Nederlandse regelgeving wordt geen voorkeur uitgesproken voor historische kosten of waardering op basis van herwaardering (actuele waarde) [Art. 384.1 en RJ 1.03].

De herziene IAS 16 (en E32, de SI en E43) stelt dat indien een materieel vast actief wordt verworven in ruil voor gelijk- of ongelijksoortige activa, waardering mag plaatsvinden tegen reële waarde of netto boekwaarde van het ingeruilde actief. Indien een materieel vast actief wordt verworven in ruil voor een ongelijksoortig actief dient waardering plaats te vinden tegen reële waarde (waardering tegen netto boekwaarde van het ingeruilde actief is niet toegestaan, in tegenstelling tot de oude standaard IAS 16). In geval van inruil van een gelijksoortig actief dient waardering plaats te vinden tegen netto boekwaarde van het ingeruilde actief (reële waarde is niet toegestaan, in tegenstelling tot de oude IAS 16). Nederland bevat op dit punt geen specifieke regels.

Volgens E32, de SI, E43 en de herziene IAS 16 dienen waardestijgingen die zijn gerelateerd aan waardedalingen die in voorgaande perioden in het resultaat zijn verwerkt, in de huidige periode te worden verantwoord. Verwerking van deze waardestijging rechtstreeks in het eigen vermogen is niet toegestaan. Dit in tegenstelling tot de oude IAS 16, waarin beide methoden (verwerking in het resultaat en verwerking in het eigen vermogen) werden toegestaan. In Nederland zijn op dit punt geen regels.

Een wijziging in de herziene IAS 16 ten opzichte van E43 betreft de behandeling van een wijziging in de afschrijvingsmethode welke het gevolg is van een verandering van het verwachte patroon van economische voordelen dat van het actief wordt genoten. In E43 werd geëist dat deze verandering van afschrijvingsmethode werd behandeld als een stelselwijziging. Dit in tegenstelling tot de herziene IAS 16 die voorschrijft dat in dat geval sprake is van een schattingswijziging. Ook volgens de Nederlandse richtlijnen is in deze situatie sprake van een schattingswijziging [RJ 2.02.220].

\section{IAS 19 [E47] Retirement Benefit Costs}

De standaard behandelt de verwerking van pensioentoezeggingen in de jaarrekening van werkgevers.

Volgens de oude standaard IAS 19 'Accounting for Retirement Benefits in the Financial Statement of Employers' (december 1982) waren er twee berekeningswijzen van pensioenlasten. De eerste manier is volgens het koopsommenstelsel, de zogenaamde 'opgebouwde rechten methode' ('accrued benefit valuation method'), waarbij de pensioenlasten worden berekend met behulp van een actuariële methode die is gebaseerd op de verstreken diensttijd. De tweede manier is berekening van de pensioenlasten volgens het premiestelsel, de zogenaamde 'anticipatiemethode' ('projected benefit valuation method'), welke methode rekening houdt met zowel verstreken als toekomstige diensttijd.

In E32, in de SI, in E47 en in de herziene IAS 19 is als voorkeursmethode de 'opgebouwde rechtenmethode' aangegeven, met als toegestane alternatieve methode de 'anticipatiemethode'. Werd in E32 nog een reconciliatie met de voorkeursmethode geëist (indien de praktische bezwaren niet te groot waren), in de herziene IAS 19 is deze eis vervallen. In de Nederlandse richtlijnen ${ }^{20}$ wordt geen voorkeur aangegeven met betrekking tot de te hanteren methode om de pensioenlast te berekenen [RJ 2.53.304-305]. 
Bij beide methoden was het volgens de oude IAS 19 toegestaan rekening te houden met toekomstige salarisveranderingen. De herziene IAS 19 (en E32. de SI en E47) verplicht bij beide methoden rekening te houden met toekomstige salarisveranderingen. In Nederland is het zo dat alhankelijk van de gehanteerde methode (stelsel) men met toekomstige salarisveranderingen rekening kan houden |RJ $2.53 .305 \mathrm{c} \mid$. Het rekening houden met tockomstige salarisstijgingen is in ons land ongebruikelijk en past niet goed bij een lage rekenrente.

Mel betrekking tol de bestalande werknemers is in de oude IAS 19 toegestaan, pensioenlasten betrekking hebbend op verstreken dienstjaren oftewel backservicelasten ('past service costs'), ervaringsaampassingen, ('experience adjustments'), aumpassingen van de pensioenregeling ('plan amendments') en veranderingen in actuariële grondslagen op twee wijzen te verwerken. Ten eerste door ze op systematische wijze aan de gemiddelde resterende arbeidsperiode toe te rekenen. Ten tweede. door ze op het moment dat ze zich voordocn in het resultat op te nemen. De eerste verwerkingswijze (systematisch toerekenen) wordt in de herziene IAS 19 (en E32, de SI en E47) voorgeschreven. Men mag deze lasten dus niet meer op het moment van ontstaan in het resultaat opnemen. In Nederland dient onvoorwaardelijke backservice, voorzover niet reeds gefinancierd. in de balans te worden opgenomen. Reeds gefinancierde onvoorwaardelijke backservice dient onmiddellijk ten laste van het resultaat te worden gebracht [RJ 2.53.31 I*]. De Nederlandse regels wijken hier dus af van de herziene IAS 19. 'Experience adjustments', m.n. verliczen. worden in ons land meteen genomen.

Tekorten c.q. overschotten in het pensioenfonds dienen volgens de oude en herziene IAS 19 te leiden tot aanpassing van de te betalen premie en dus tot aanpassing van de pensioenkosten over komende perioden. In Nederland vormen tekorten en overschotten in pensioenfondsen geen rechtstreekse determinanten van de pensioenkosten van de onderneming. De te betalen jaarpremie dient als kosten te worden genomen. Voor tekorten in pensioenfondsen dient een voorziening te worden gevormd [RJ 2.53.318*] en overschotten in pensioenfondsen mogen niet worden geactiveerd [RJ 2.53.318*-320].

In de herziene (en oude) IAS 19 wordt uitge- breide informatie in de toelichting met betrekking tot pensioenregelingen op basis v'an salaris/ diensttijdregelingen ('defined benefit plans') vereist. De Nederlandse regels eisen hieromtrent slechts beperkte informatie in de toelichting [Art. 384.5 en RJ 2.53.323].

Tot slot zijn in de herziene IAS 19 ten opzichte van E47 nog wijzigingen aangebracht in de reikwijdte van de standaard. de definitie van 'past service costs" en de in de toelichting te verstrekken informatie.

\section{IAS 2I [E44] The Effects of Changes in Foreign Exchange Rates}

De standaard bevat de administratieve verwerking van wijzigingen in valutakoersen in de jaarrekening van ondernemingen.

Ten aanzien van vorderingen en schulden samenhangende met langlopende transacties (lange termijn monetaire posten) zonder dekking ran het koersrisico was in de oude IAS 21 'Accounting for the Effects of Changes in Foreign Exchange Rates' (juni 1983) opgenomen: koersverschillen dienen onmiddellijk in de winst-en verliesrekening te worden opgenomen. Aanvaardbaar was de koersverschillen uit te stellen (te activeren) en op systematische basis aan de resterende looptijd toe te rekenen, met dien verstande dat koersverliezen niet mochten worden uitgesteld indien er een redelijke verwachting was dat zij in de toekomst groter zouden worden. Volgens de herziene IAS 21 (en E32, de SI en E44) is dit laatste (het uitstellen van koersverschillen) niet langer toegestaan. Volgens de Nederlandse richtlijnen dienen koersverschillen ten laste van het resultaat te worden gebracht in de periode waarin zij ontstaan [RJ 2.03.909-910]. Het is echter als alternatief aanvaardbaar koerswinsten op een systematische wijze toe te rekenen aan de resterende looptijd van de transactie [RJ 2.03.910].

Met betrekking tot vorderingen en schulden samenhangende met langlopende transacties met dekking van het koersrisico was in de oude IAS 21 het volgende opgenomen: alle koersverschillen (termijnkoers minus contante koers) dienden systematisch over de looptijd van het termijncontract in de winst- en verliesrekening te worden opgenomen. De herziene IAS 21 [paragraaf 2] vermeldt dat 'hedge accounting ' (afdekking van koersrisico) betreffende posten in vreemde valuta 
zal worden behandeld in het kader van het 'Financial Instruments Project'. In E48 'Financial Instruments' is, evenals in E44. de verplichting opgenomen om alle koersresultaten over de looptijd van het termijncontract te verdelen. De Nederlandse richtlijn komt overeen met de oude IAS 21 [RJ 1.03.911], behalve op het punt van de koersverliezen. Koersverliezen mogen tevens direct in de resultatenrekening worden verwerkt [RJ 1.03.911*].

\section{Koersverschillen over leningen in vreemde} valuta die zijn afgesloten met het oog op afdekking van toekomstige kasstromen moesten volgens de oude IAS 21 over de looptijd van het termijncontract in de winst- en verliesrekening worden opgenomen. In E32, de SI, E44 en E48 wordt de mogelijkheid geboden deze verschillen uit te stellen en ze pas bij afloop respectievelijk aflossing als resultaat te verantwoorden. Voor de herziene IAS 21: zie vorige alinea. Ook de Nederlandse richtlijn 1.03 .911 biedt de laatstgenoemde mogelijkheid.

Koersverliezen welke het gevolg zijn van zware devaluatie waartegen geen dekking mogelijk is, mochten volgens de oude IAS 21 in de winst- en verliesrekening worden opgenomen. Het was tevens toegestaan de verliezen te activeren bij de gerelateerde activa. De Nederlandse richtlijnen bevatten op dit punt geen speciale regels.

Ten aanzien van de omrekening van de in vreemde valuta gestelde posten van de winst-en verliesrekening van buitenlandse entiteiten (deelnemingen) stelde de oude IAS 21: hetzij tegen koersen per balansdatum (eindkoers), hetzij tegen koersen per transactiedatum (of een benadering daarvan: gemiddelde koersen). Het verschil met de omrekening van de balans tegen koersen per balansdatum mocht worden verwerkt via het eigen vermogen of via de winst- en verliesrekening. In de herziene IAS 21 (en in E32, de SI en E44) wordt voorgeschreven de koersen per transactiedatum (of benadering daarvan: gemiddelde koersen) te gebruiken; omrekening tegen koersen per balansdatum is niet langer toegestaan. Het omrekeningsverschil dient in het eigen vermogen te worden verwerkt; verwerking via de winsten verliesrekening is niet langer toegestaan. In de Nederlandse richtlijn is opgenomen dat de winst- en verliesrekening van een buitenlandse entiteit moet worden omgerekend tegen hetzij de eindkoers, hetzij de gemiddelde koers [RJ 1.03.919]. Het omrekeningsverschil dat ontstaat bij gebruik van de gemiddelde koers respectievelijk de eindkoers, dient te worden verwerkt in het eigen vermogen, respectievelijk de winst- en verliesrekening [RJ 1.03.919*]. In Nederland wordt door een belangrijk aantal ondernemingen de koers op balansdatum gebruikt voor alle posten van de jaarrekening, inclusief de winst- en verliesrekening. Een aanzienlijk aantal past voor de winst-en verliesrekening echter een gemiddelde koers toe. ${ }^{21}$

Koersverschillen als gevolg van de omrekening van jaarrekeningen van rechtstreekse buitenlandse activiteiten dienden volgens de oude IAS 21 te worden opgenomen in de winst-en verliesrekening, behoudens dat koersverschillen verband houdende met langlopende monetaire posten konden worden uitgesteld en uitgesmeerd. Koersverliezen mochten echter niet worden uitgesteld indien er een redelijke verwachting was dat zij in de toekomst groter zouden worden. Tevens was het mogelijk in geval van een koersverschil welke het gevolg was van een zware devaluatie waartegen geen dekking mogelijk was, het verschil in de boekwaarde van de betreffende activa te verwerken. In de herziene IAS 21 (en in E32, de SI en E44) is dit laatste (verwerking in de boekwaarde) het toegestane alternatief en verwerking in de winst- en verliesrekening de voorkeursmethode (tenzij afgedekt). Uitstellen en uitsmeren van koersverschillen is niet langer toegestaan. In de Nederlandse richtlijnen is slechts de bepaling opgenomen dat omrekeningsverschillen op rechtstreekse buitenlandse activiteiten dienen te worden opgenomen in de winst- en verliesrekening [RJ $1.03 .926 *]$.

Met betrekking tot de 'vertaling'van de jaarrekening van buitenlandse entiteiten die rapporteren in de valuta van een hyperinflatieland was in de oude IAS 21 opgenomen dat dit mocht plaatsvinden zowel vóór als na aanpassing voor hyperinflatie. De herziene IAS 21 stelt verplicht dat deze 'vertaling' niet mag plaatsvinden vóór aanpassing voor hyperinflatie. Ook in de Nederlandse richtlijnen is opgenomen dat de 'vertaling' dient plaats te vinden vóór aanpassing van hyperinflatie [RJ 1.03.918*]. Als alternatief is het volgens de Richtlijn toelaatbaar de niet- 
monetaire activa tegen historische koersen om te rekenen [RJ 1.03.918].

Volgens de oude IAS 21 diende de onderneming voor elke buitenlandse activiteit te bepalen of het een activiteit in buitenlandse eenheden of een rechtstreekse buitenlandse activiteit was. Volgens de Nederlandse richtlijnen is het om praktische redenen toegestaan om op grond van het karakter van de belangrijkste buitenlandse activiteiten, alle buitenlandse activiteiten waarvan de gegevens in de geconsolideerde jaarrekening worden opgenomen, òf als activiteiten in buitenlandse eenheden, of als rechtstreekse buitenlandse activiteit te behandelen [RJ 1.03.914].

In de herziene IAS 21 zijn ten opzichte van E44 nog een aantal veranderingen aangebracht. zoals hel eisen van informatie ten aanzien van koersverschillen (indien deze wel zouden worden geactiveerd) in de toelichting. Ook dient volgens de nieuwe IAS 21 informatie in de toelichting te worden opgenomen omtrent de aard van de redenen en de invloed van een wijziging in de classificatie van een buitenlandse activiteit.

Tot slot dient te worden opgemerkt dat in de Nederlandse wet slechts is bepaald dat de grondslagen voor de omrekening van de in vreemde valuta luidende bedragen worden uiteengezet en dat wordt vermeld op welke wijze koersverschillen zijn verwerkt [Art. 384.5].

\section{IAS 22 [E45] Business Combinations}

De standaard behandelt de administratieve verwerking van fusies en overnames.

Volgens de oude IAS 22 'Accounting for Business Combinations' (november 1983) konden zowel fusies ('uniting of interests') als overnames ('acquisitions') worden verantwoord volgens de 'Pooling of interest'-methode of de 'Purchase methode. Bij de 'Pooling of Interests'-methode worden de samengevoegde activa en passiva tegen hun bestaande boekwaarden opgenomen. Bij de 'Purchase'-methode dienen de overgenomen onderscheidbare activa en passiva te worden opgenomen tegen hun reële waarde ('fair values') op het moment van overname. Het verschil met de betaalde koopprijs is dan positieve dan wel negatieve goodwill.

In E32, de SI, E45 en in de herziene IAS 22 is het volgende opgenomen. Overnames moeten volgens de 'Purchase'-methode en fusies moeten volgens de 'Pooling of Interests'-methode worden verwerkt. De 'Purchase'-methode gebruiken voor de verwerking van fusies is dus niet langer toegestaan. Van fusies is slechts in uitzonderingsgevallen sprake, o.a. indien geen echte overnemende onderneming kan worden vastgesteld. In de Nederlandse richtlijnen wordt de 'Pooling of Interest'-methode niet behandeld.

Naast activeren en op systematische grondslag afschrijven over de gebruiksduur van positieve goodwill, was het in de oude IAS 22 toegestaan positieve respectievelijk negatieve goodwill direct ten laste respectievelijk ten gunste van het eigen vermogen te brengen. In de herziene IAS 22 (en $\mathrm{E} 32$, de SI en E45) is opgenomen dat positieve goodwill dient te worden geactiveerd en te worden afgeschreven over de gebruiksduur. Deze afschrijvingsperiode mag maximaal vijf jaar zijn, tenzij de goodwill aan een langere periode van maximaal twintig jaar (welke periode de onderneming aannemelijk moet kunnen maken en moet toelichten) kan worden toegerekend. De optie directe afboeking van het eigen vermogen van positieve goodwill is geëlimineerd.

De Nederlandse regelgeving staat toe positieve goodwill rechtstreeks ten laste van het eigen vermogen te boeken [Art. 389.5 en RJ 2.03.220]. Daarnaast is het mogelijk positieve goodwill te activeren en over de economische gebruiksduur af te schrijven, met een maximum van vijf jaar. Indien de onderneming echter kan aantonen dat de economische levensduur langer dan vijf jaar is, mag over deze langere periode worden afgeschreven (hierbij geen maximum van twintig jaar zoals in de herziene IAS 22 is opgenomen) [Art. 386.3]. In de Nederlandse verslaggevingspraktijk komt activeren en afschrijven van goodwill betrekkelijk weinig voor.?

De voorkeursmethode betreffende de verwerking van negatieve goodwill is het toerekenen aan niet monetaire activa die zijn verworven. Indien na deze toerekening nog negatieve goodwill resteert dient de onderneming deze te behandelen als uitgestelde opbrengsten (met andere woorden als overlopende post) en vervolgens ze systematisch ten gunste van het resultaat te brengen op dezelfde wijze als positieve goodwill (maximaal vijf jaar. eventueel maximaal 20 jaar). Een toegelaten altematief is om de negatieve goodwill niet toe te rekenen aan individuele activa, maar volledig als overlopende post te behandelen en systematisch ten gunste van het resultaat te brengen op dezelfde 
wijze als positieve goodwill (maximaal vijf jaar, eventueel maximaal 20 jaar). De optie om negatieve goodwill te verwerken in het eigen vermogen is geëlimineerd. Negatieve goodwill dient volgens de Nederlandse regels te worden opgenomen in een herwaarderingsreserve (dus in het eigen vermogen; in tegenstelling tot herziene IAS 22) [RJ 2.03.225*].

\section{Minderheidsbelangen die ontstaan bij een} fusie of overname konden volgens de oude IAS 22 worden gewaardeerd op basis van boekwaarden vóór de overname/fusie of tegen reële waarden ('fair values') ná de overname/fusie. In de herziene IAS 22 (en E32, de SI en E44) gaat de voorkeur uit naar waardering op basis van boekwaarden vóór de overname/fusie. Toegestaan alternatief is waardering tegen reële waarden ('fair values') ná de overname/fusie.

Naar aanleiding van commentaren op E45 zijn in de herziene IAS 22 ten opzichte van E45 nog de volgende veranderingen doorgevoerd: er dient aanvullende informatie omtrent verwerkte verplichtingen bij overnames in de toelichting te worden opgenomen, zoals kosten van het sluiten van een bedrijf en reorganisatiekosten. Tevens, indien goodwill op een andere wijze wordt afgeschreven dan lineair, dient dit gemotiveerd te worden toegelicht. Daarnaast is in de herziene IAS 22 een toelichting toegevoegd over de verwerking van juridische fusies.

\section{IAS 23 [E39] Borrowing Costs}

De standaard behandelt de administratieve verwerking van kosten van leenvermogen.

De oude standaard IAS 23 'Capitalisation of Borrowing Costs' (april 1984) stond ten aanzien van de verwerkingswijze van kosten van leenvermogen een vrije keuze toe tussen activering en het direct ten laste van de winst- en verliesrekening brengen van deze kosten met betrekking tot uitgaven voor langlopende activa.

In E32 werd als voorkeursmethode opgenomen het direct ten laste van de winst- en verliesrekening brengen van de kosten van leenvermogen, met als toegestane alternatieve verwerkingswijze de activering van de kosten. Naar aanleiding van commentaren op E32 werd in de SI en in E39 voorgeschreven de kosten van leenvermogen te activeren.

In de herziene IAS 23 is echter, naar aanleiding van commentaren op E39, teruggekeerd naar de eerdere positie: voorkeur heeft het direct ten laste van de winst- en verliesrekening brengen van de kosten van leenvermogen, met als toegestaan alternatief het activeren van deze kosten (indien de periode, vanaf het tijdstip van aanvang van de activiteiten tot het tijdstip waarop het actief gereed is voor gebruik of verkoop, substantieel is).

Volgens de Nederlandse wet is het toegestaan de kosten van leenvermogen over het tijdvak dat aan de vervaardiging van het actief kan worden toegerekend, op te nemen in de vervaardigingsprijs. Hiervan dient in de toelichting melding te worden gemaakt [Art. 388.2]. Voorts dient volgens RJ 2.02.303* het bedrag te worden vermeld dat gedurende de verslagperiode aan rente is geactiveerd.

\section{Afsluiting}

In het kader van het 'Comparability/Improvements Project' (E32) zijn door de Board van het IASC in november 1993 een tiental (herziene) standaards goedgekeurd. Ten aanzien van een aantal verwerkingswijzen is in de herziene standaards een verwerkingsmethode verplicht gesteld. Voor een aantal andere verwerkingswijzen zijn een voorkeursmethode ('benchmark treatment') en een alternatieve verwerkingsmethode toegestaan ('allowed alternative treatment'). Werd in E32 nog bij gebruik van de alternatieve verwerkingsmethode de aanvullende eis gesteld dat deze methode alleen was toegestaan indien de onderneming in de toelichting tot uitdrukking bracht welk effect toepassing van de alternatieve methode in vergelijking met de voorkeursmethode heeft op vermogen en resultaat, in de herziene standaards is deze eis (behoudens enkele uitzonderingen), als gevolg van het vele commentaar dat hierop is gekregen, vervallen.

In de herziene standaards zijn dus een aantal opties die in de oude standaards werden toegelaten, niet langer toegestaan. De belangrijkste opties die zijn vervallen betreffen de volgende:

- het ijzeren voorraadstelsel is niet langer toegestaan (IAS 2);

- de 'Completed Contract'-methode bij de winstneming op bouw- en dienstverleningscontracten is in principe niet langer toegestaan. Men dient de 'Percentage of Completion'methode te gebruiken (IAS $1 /$ en IAS I8);

- bij de berekening van de pensioenlasten moet de werkgever rekening houden met toekomstige salarisveranderingen. Hiermee geen rekening houden is niet langer toegestaan (IAS 2I); 
- backservicelasten e.d. dienen te worden verwerkt in de winst- en verliesrekening over de gemiddelde resterende arbeidsperiode van de bestaande werknemers en verwerking is in de winst- en verliesrekening op het moment van ontstaan van de lasten niet langer toegestaan (IAS 19);

- koersverschillen in verband met vorderingen en schulden samenhangende met langlopende transacties zonder dekking van het koersrisico en in verband met de omrekening van jaarrekeningen van geïntegreerde buitenlandse activiteiten mogen niet meer worden uitgesteld en geamortiseerd (IAS 21);

- de winst- en verliesrekening van een buitenlandse entiteit (dochteronderneming) luidend in vreemde valuta mag niet meer tegen eindkoers worden omgerekend, maar moet tegen gemiddelde koers worden omgerekend (IAS 21);

- bij fusie wordt de 'pooling of interest'-methode slechts bij hoge uitzondering (in geval er geen overnemende partij kan worden vastgesteld) toegestaan (IAS 22);

- positieve respectievelijk negatieve goodwill mag niet meer ten laste, respectievelijk ten gunste, van het eigen vermogen worden geboekt (IAS 22).

Om een indruk te krijgen van de mate waarin en de punten waarop de Nederlandse regels moeten worden aangepast indien de eisen in de IASC-standaards worden overgenomen, is in dit artikel tevens de Nederlandse regelgeving (wetgeving en de Richtlijnen voor de Jaarverslaggeving) in het kader van de herziene IASC-standaards aangegeven en de belangrijkste verschillen daartussen. De belangrijkste verschillen betreffen:

- het ijzeren voorraadstelsel (IAS 2: niet toegestaan);

- de definitie van het begrip 'buitengewone baten en lasten' (IAS 8: beperkt);

- verstrekking van informatie met betrekking tot beëindigde activiteiten (IAS 8: veel);

- 'Completed Contract'-methode (IAS II en IAS 18: niet toegestaan);

- reeds gefinancierde onvoorwaardelijke backservice onmiddellijk ten laste van het resultaat brengen (IAS 19: niet toegestaan);

- uitstellen van koersverschillen op vorderingen en schulden samenhangende met langlopende transacties zonder dekking van het koersrisico (IAS 21: niet toegestaan);
- omrekening van de in vreemde valuta gestelde posten van de winst- en verliesrekening van buitenlandse entiteiten tegen eindkoers (IAS 21: niet toegestaan);

- positieve en negatieve goodwill onmiddellijk verwerken in het eigen vermogen (IAS 22: niet toegestaan).

Met het niet langer toestaan van een belangrijk aantal opties in de herziene standaards is een goede stap op de weg naar internationale vergelijkbaarheid gezet. Het valt te verwachten dat het IASC op de ingeslagen weg zal voortgaan. Door de Raad voor de Jaarverslaggeving is nog veel werk te doen. ${ }^{23}$

\section{I T E R A T U U R}

Arnold, C.A. en H.N.M. van der Voorn, Rapportering volgens de IASC-standaards - Effecten van verschillen tussen de Nederlandse en IASC-verslaggevingsgrondslagen, MAB (nog te verschijnen).

Cairns, D., (1989), IASC; a new approach, De Accountant, no. 2, oktober.

Coopers \& Lybrand International, (1993), International Accounting Summaries, Second edition.

FEE, (1991), European Survey of Published Accounts 1991, Brussel, FEE.

FEE, (1992), Analysis of European Accounting and Disclosure Practice 1992, Brussel, FEE.

Helleman, J. van, (1989), Vergelijkbaarheid van jaarrekeningen, De Accountant, no. 6, februari.

Helleman, J. van, (1990), Internationale vergelijkbaarheid van jaarrekeningen, in: Vergelijkbaarheid van jaarrekeningen, Kluwer Bedrijfswetenschappen, Deventer.

Hoepen, M.A. van, (1989), Onderhanden werk in de jaarrekening, in: Ontwikkelingen in de financiële verslaggeving: grondslagen en praktijk, Kluwer Bedrijfswetenschappen, Deventer

Hulle, K. van, (1989), Harmonisatie van de regels inzake financiële verslaggeving in de EG, De Accountant, no. 11, juli/augustus.

IASC, (1993), International Accounting Standards, Current and projected status, London, juli.

IASC, (1993), Comparability of Financial Statements, Revised International Accounting Standards 1993, London, december, $209 \mathrm{p}$.

IASC, (1993), International Accounting Standards, in: Documentatie rond de jaarrekening, Kluwer Bedrijfswetenschap. pen, februari. 
IASC, (1993), Survey of the Use and Application of International Accounting Standards, London, september.

Klaassen, J., (1990), Vergelijkbaarheid van financiële informatie, De Accountant, no. 6, april.

NIVRA, (1992), Onderzoek Jaarverslaggeving 1990, Nivra geschriften no. 60, Kluwer Bedrijfswetenschappen, Deventer. Raad voor de jaarverslaggeving, (1993), Richtliinen voor de Jaarverslaggeving, Kluwer Bedrijfswetenschappen, november. Raad voor de jaarverslaggeving, (1989), Commentaar op E32 'Comparability of Financial Statements', De Accountant, oktober.

Tas, L.G. van der, (1991), Harmonisation of financial reporting-With a special focus on the European Community, Datawyse, Maastricht.

Vergoossen, R.G.A., Rapportering 'on Form 20-F', Maandblad voor Accountancy en Bedriffsadministratie, oktober 1990. pag. 456-469.

\section{NOTE N}

1 De auteur is de heer Prof. Dr. J. Klaassen erkentelijk voor zijn waardevolle commentaar op de conceptversie van dit artikel. De verantwoordelijkheid voor de inhoud van het artikel berust geheel bij de auteur persoonlijk.

2 De Nederlandse (ontwerp)richtlijnen uitgevaardigd tot en met januari 1994. Stellige uitspraken in de (ontwerp)richtlijnen worden met een * aangegeven.

3 De IASC-standaards en ED's uitgevaardigd tot en met januari 1994.

4 Klaassen, J., 1990, pag. 435.

5 Coopers \& Lybrand International, 1993, pag. EUR-2.

6 Hulle, K. van, 1989, pag. 541.

7 Federation des Expert Comptables Europeens (FEE), 1991 en 1992.

8 Federation des Expert Comptables Europeens (FEE), 1991 en 1992.
9 Federation des Expert Comptables Europeens (FEE), 1991 en 1992.

10 IASC, september 1993

11 IASC, september 1993

12 Zie Federation des Expert Comptables Europeens (FEE), 1991 en 1992.

13 Zie C.A. Arnold.

14 Art. 385.2 luidt: de waardering van gelijksoortige bestanddelen van voorraden en effecten mag geschieden met toepassing van gewogen gemiddelde prijzen, van de regels 'eerst-in, eerst-uit' (Fifo), 'laatst-in', 'laatst-uit' (Lifo), of van soortgelijke regels. Gezien de nauwe verwantschap tussen het Lifo-stelsel en het ijzeren-voorraadstelsel kan laatstgenoemd stelsel als 'soortgelijke regel' in de zin van de wet worden aangemerkt [RJ 2.11.205].

15 NIVRA, 1992, vraag 4.03, pag. 76.

16 NIVRA, 1992, vraag 7.14 en 7.15, pag. 138.

17 NIVRA, 1992, vraag 3.03, pag. 33.

18 Hoepen, M.A. van, 1989, pag. 87-88.

19 Helleman, J. van, 1990, pag. 12.

20 Men dient zich te realiseren dat de Amerikaanse pensioenregeling model heeft gestaan voor de IASC-standaard en dat er tussen de pensioenregelingen in Nederland en de Verenigde Staten structurele verschillen bestaan. Verschillen tussen de IASC-regels en de Nederlandse regels kunnen dan ook voortkomen uit deze structurele verschillen.

21 NIVRA, 1992, vraag 7.05, pag. 136.

22 NIVRA, 1992, vraag 3.05, pag. 35.

23 De Raad voor de Jaarverslaggeving heeft in een reactie op E32 aangegeven dat zij 'overriding objections' had tegen het verplicht stellen van een verwerkingsmethode, uitsluitend op grond van 'presumed world practice', terwijl een andere verwerkingsmethode tot een beter inzicht in het vermogen en resultaat zou leiden (Raad voor de Jaarverslaggeving, 1989). Aangezien in de herziene Standaards een aantal verwerkingsmethoden verplicht is gesteld (zonder dat een alternatieve methode is toegestaan), valt te betwijfelen of de Raad voor de Jaarverslaggeving de betreffende IASC-eisen in de Nederlandse Richtlijnen zal verwerken. 